\title{
Effektiewe bestuur op die onderleidingvlak
}

\author{
F.W. Marx \\ Departement Bedryfsekonomie, Universiteit van Pretoria, Pretoria
}

\begin{abstract}
Effectlve management at the lower lovel. It is essential that the productivity performance of the South African worker be improved considerably. It is belleved that lower management, being in the position of direct supervisors of the low level workforce, can make an important contribution in this direction. Effective management at the lower level, however, requires thorough training in order to make the supervisor aware of the technical and especially the human requirements of his difficult task.

A recent survey has revealed that South African companies are not using motivation theories and teaching methods to a large extent in respect of lower management. It appears, therefore, that effective management at the lower level is not receiving sufficient attention.

The difficult task of the supervisor is elucidated and several suggestions given for furthering effective management at the lower level.

S. Afr. J. Bus. Mgmt. 1983, 14:113-119

Die verhoging van die produktiwiteit van die Suid-Afrikaanse werker is 'n saak van dringende belang. Die onderleiding as die direkte toesighouers oor die laevlakwerkers kan hiertoe 'n belangrike bydrae lewer. Effektiewe bestuur op die onderleidingvlak vereis egter deeglike opleiding om die toesighouer bewus te maak van die tegniese en veral die menslike vereistes van sy veeleisende taak.

'n Onlangse ondersoek toon egter dat Suid-Afrikaanse ondernemings nie op groot skaal van motiveringsteorieé en opleidingsmetodes op die onderleidingviak gebruik maak nie. Dit word dus betwyfel of die bevordering van effektiewe bestuur op die onderleidingvlak voldoende aandag ontvang.

Die veeleisende taak van die toesighouer word loegatig en wenke aan die hand gedoen om effektiewe bestuur op die onderleidingvlak te bevorder.

S.Afr. Tydskr. Bodryfsl. 1983, 14: 113-119
\end{abstract}

Prof. F.W. Marx

Departement Bedryfekonomie, Universiteit van Pretoria,

Hillcrest, Pretoria 0083, Republiek van Suid-Afrika

\section{Inleiding}

Die noodsaaklikheid om produktiwiteit in Suid-Afrika te verhoog, geniet vandag wye belangstelling. Produktiwiteitsverhoging word beskou as een van die belangrikste middele tot ons beskikking om ekonomiese vraagstukke soos die bekamping van inflasie, die bevordering van ekonomiese groei en werkverskaffing, die tekort aan opgeleide mannekrag en uitvoerbevordering die hoof te bied. Dat SuidAfrika se produktiwiteitsprestasies swak vergelyk met talle oorsese lande is 'n bekende feit. Onlangs is byvoorbeeld beweer dat die produktiwiteit van een Taiwanese werker in die tekstiel- en klerebedryf gelyk is aan dié van sewe sulke werkers in Suid-Afrika. ${ }^{1}$

Die besonder belangrike rol van die bestuur op alle vlakke in pogings om produktiwiteit te verhoog, word dikwels beklemtoon. In hierdie artikel val die klem op die onderleidingvlak, dit wil sê daardie bedryfsleiers wat vir die direkte toesighouding oor die laevlakwerkers verantwoordelik is. Hulle is in daaglikse kontak met die uitvoering van die aktiwiteite en kan dus ' $n$ direkte en beslissende invloed uitoefen op die prestasies van die ondergeskiktes. Hulle sal egter nie veel sukses behaal indien daar nie toegesien word dat hulle behoorlik vir hul taak opgelei is nie. In besonder moet hulle daartoe in staat wees om hul ondergeskiktes so te lei dat hulle potensiaal ten beste benut kan word. Die werkers se vermoë om' $n$ taak uit te voer moet omgesit word in 'n bereidwilligheid om die tauk so goed moontlik uit te voer. ' $n$ Toesighouer moet dus weet hoe om sy ondergeskiktes te motiveer sodat hulle hul beste prestasies sal lewer. Dit sal hy alleen kan doen indien hy oor voldoende kennis omtrent die verskillende motiveringsteorieë beskik.

\section{Die gebrulk van motiveringsteoriee en opleidings. metodes ten opsigte van die onderleidingulak}

'n Onlangse navorsingsprojek ${ }^{2}$ het getoon dat SuidAfrikaanse ondernemings nie op groot skaal van motiveringstoerieë en opleidingmetodes ten opsigte van die onderleidingvlak gebruik maak nie. Altesaam 128 ondernemings uit al vier provinsies en uit feitlik alle sektore van die landsekonomie, met 'n totale werknemerskorps van ongeveer 450000 en waarvan $56,2 \%$ oor meer as 1000 personeellede beskik, het aan die ondersoek deelgeneem. Tabel 1 verstrek besonderhede oor die persentasie deelnemers wat die verskillende persone se motiveringsteoriee//idees ten opsigte van die onderleidingvlak gebruik het, die persentasie deelnemers wat ten opsigte van elke teorie geen sukses of $1 \%$ tot $49 \%$ sukses of $50 \%$ tot $100 \%$ sukses behaal het, en die 
Tabel 1 Die gebruik van motiveringsteorieë en opleidingsmetodes ten opsigte van die onderleiding

\begin{tabular}{|c|c|c|c|c|c|c|}
\hline Motiveringsteorie & $\frac{\% \text { gebruikers }}{\%}$ & $\frac{\text { Geen sukses }}{\%}$ & $\begin{array}{c}\begin{array}{c}1 \% \text { tot } 49 \% \\
\text { sukses }\end{array} \\
\% \%\end{array}$ & $\begin{array}{c}50 \% \text { tot } 100 \% \\
\text { sukses }\end{array}$ & Opleidingsmetode & $\begin{array}{c}\% \\
\text { gebruikers } \\
\%\end{array}$ \\
\hline Mayo & 11,7 & - & 53,3 & 46,7 & Lesings & 46,1 \\
\hline Roethlisberger & 2,3 & - & 100,0 & - & Kortkursusse & 66,4 \\
\hline McGregor & 34,4 & 2,3 & 70,4 & 27,3 & Seminare & 64,8 \\
\hline Maslow & 39,8 & - & 53,0 & 47,0 & Besprekings & 59,4 \\
\hline Herzberg & 39,8 & - & 58,8 & 41,2 & Gevallestudies & 46,1 \\
\hline McClelland & 14,9 & - & 57,9 & 42,1 & Rolspel & 40,6 \\
\hline Likert & 11,7 & 6,6 & 66,7 & 26,7 & Simulasie & 24,2 \\
\hline Vroom & 4,7 & - & 66,7 & 33,4 & Bestuurspele & 23,4 \\
\hline Lawler & 6.3 & - & 62,5 & 37,5 & $\begin{array}{l}\text { Geprogrammeerde } \\
\text { onderrig }\end{array}$ & 26,6 \\
\hline Schein & 6,3 & - & 75,0 & 25,0 & Sensitiwiteitsopleiding & 9,4 \\
\hline Skinner & 8,6 & - & 45,4 & 54,6 & Bestuursrooster & 16,4 \\
\hline Blake en Mouton & 22,7 & 3,4 & 62,2 & 34,4 & Doelwitbestuur & 47,7 \\
\hline Gellerman & 10,2 & - & 69,2 & 30,8 & Taakverryking & 29,7 \\
\hline Ander ${ }^{2}$ & 6,3 & - & 25,0 & 75,0 & $\begin{array}{l}\text { Organisasie- } \\
\text { ontwikkeling }\end{array}$ & 32,0 \\
\hline \multirow[t]{3}{*}{ Totaal } & - & 1,1 & 60,1 & 38,8 & Gedragsmodellering & 31,2 \\
\hline & & & & & Selfstudie & 50,8 \\
\hline & & & & & Ander ${ }^{b}$ & 3,1 \\
\hline
\end{tabular}

" Hierdie sluit in: W.J. Reddin; Mintzberg; J. Window; E. Berne; Hersey en Blanchard; L.A. Allen; B. Byham; Kepner en Tregoe

b Hierdie sluit in: Gedragsanalise; transaksie-analise; waarderingsentrums; en L.A. Allen

persentasie deelnemers wat die verskillende opleidingsmetodes ten opsigte van die onderleidingvlak gebruik het.

Wat die gebruik van motiveringsteorieë betref, is die bevindinge redelik teleurstellend aangesien geeneen van hulle deur $40 \%$ van die deelnemers ten opsigte van die onderleiding gebruik is nie. Slegs drie persone se teorieë is deur meer as $30 \%$ van die deelnemers gebruik, naamlik McGregor, Maslow en Herzberg. Slegs die teorie van Blake en Mouton is deur meer as $20 \%$ van die deelnemers toegepas.

Die sukses wat met die gebruik van die motiveringsteorieë behaal is, is eweneens teleurstellend. Drie teoriee is sonder enige sukses aangewend, terwyl 'n suksespersentasie van $50 \%$ en meer deur slegs $38,8 \%$ van die deelnemers behaal is. Nie minder nie as $60,1 \%$ van die deelnemers se sukses was minder as $50 \%$.

Die resultate in verband met die gebruik van opleidingsmetodes is effens beter aangesien twee metodes deur meer as $60 \%$ van die deelnemers en twee ander metodes deur meer as $50 \%$ van die deelnemers ten opsigte van die onderleiding gebruik is. In die algemeen is die persentasie deelnemers wat opleidingsmetodes gebruik heelwat hoër as dié wat motiveringsteorieë toepas.

\section{Die moeillke taak van dle onderleiding}

Die belangrike maar moeilike posisie waarin die toesighouer as verteenwoordiger van die onderleidingvlak verkeer, $\mathrm{kan}$ kortliks soos volg toegelig word.

Eerstens is die toesighouer verantwoordelik vir 'n groot aantal en verskeidenheid van take. Ten opsigte van die uitvoering van die aktiwiteite van sy afdeling moet hy vooruit deeglik beplan, sorg dat alle benodigdhede betyds beskikbaar is, dat die werk aan die gang gesit word, dat die beste metodes gebruik word en dat die uitvoering vlot verloop, dat struikelblokke uit die weg geruim word, dat produksiedoelwitte bereik word, en dat behoorlik rekord van al die gebeure gehou word. Hy moet verder sorg vir die instandhouding van alle soorte toerusting en hulpmiddele wat by die uitvoering van die aktiwiteite gebruik word en dat onklaar items so gou moontlik herstel en indien nodig deur ander vervang word. Hy moet toesien dat kwaliteitstandaarde ten opsigte van materiale en ander voorrade wat gebruik mag word asook ten opsigte van die gehalte werk wat gedoen word, gehandhaaf word. Hy moet steeds probeer om verbeterings aan te bring ten opsigte van metodes, prosedures, prosesse, tegnieke en selfs toerusting en ander hulpmiddele. Hy moet sorg vir goeie werktoestande soos 'n aangename, veilige en higiëniese werkplek vir al sy ondergeskiktes. Hy moet steeds probeer om die uitgawes wat aangegaan word so laag moontlik te hou, om binne die perke van die begroting te bly, om afwykings wat mag voorkom op te spoor en reg te stel. Hy moet toesien dat alle diensvoorwaardes stiptelik nagekom word en moet dus ten volle op hoogte wees met wetlike voorskrifte in dié verband asook vakunie-, nywerheidsraad- en ander ooreenkomste en beslissings. Hy moet toesien dat voldoende maar nie te veel personeellede te alle tye en onder alle omstandighede beskikbaar is. Hy moet help met die keuring van nuwe personeellede, met hulle plasing, inlywing en opleiding. Hy moet aan alle personeellede voortdurend voorligting verskaf oor hul werkmetodes en hulle probeer ontwikkel. Hy moet die prestasies van sy ondergeskiktes evalueer en aanbevelings maak oor loonverhogings, bevorderings, oorplasings en ontslag van sy personeellede. Hy moet toesien dat alle reëls, regulasies en ander voorskrifte nagekom word en waar nodig dissipline toepas. Hy moet aandag skenk aan alle klagtes, griewe en persoonlike probleme van sy ondergeskiktes en sover moontlik self bevredigende oplossings probeer vind of na bestuur op hoër vlak verwys. $\mathrm{Hy}$ moet inligting aan sy personeellede verskaf oor alle sake rakende hulle werk en werkomstandighede, soos hulle regte en voorregte, ondernemingsbeleid en -prosedures, bestuurs- 
besluite, veranderings in diensvoorwaardes, werkmetodes ensomeer. Hy moet met die personeelafdeling, as soiets bestaan, saamwerk in die bekendstelling, vertolking en toepassing van die personeelbeleid en -prosedures. Hy moet alles in sy vermoë doen om sy werkers tot beter prestasies aan te spoor. Hy moet sorg dat hy self op hoogte bly met alle besluite wat hom en sy ondergeskiktes raak, steeds probeer om sy eie bestuursvermoë te verbeter en sorg dat hy altyd ' $n$ voorbeeld stel vir sy personeellede in verband met werkywer, selfdissipline, deeglikheid ensomeer.

Tweedens het die toesighouer verpligtinge teenoor verskillende persone en is hy onderhewig aan druk uit verskeie oorde. Hy moet sy onmiddellike hoof en bestuur op hoër vlak tevrede stel ten opsigte van die uitvoering van sy afdeling se aktiwiteite. Hy moet aan ander toesighouers samewerking verleen en sorg dat verskillende afdelings se werk gekoördineer word. Hy moet sy ondergeskiktes se belange behartig en na hulle welsyn omsien. Hy moet voldoen aan die wense en voorskrifte van stafafdelings soos die personeelafdeling, die regsafdeling, kwaliteitsbeheer, die rekenmeester, die werkstudiebeamptes en andere. Hy moet goeie betrekkinge handhaaf met die vakunie en sy verteenwoordiger(s) in die onderneming. Hy ontvang dus advies, instruksies en versoeke uit verskeie oorde en moet inligting, opgawes, verslae ensomeer aan verskillende persone lewer. Hy moet dus mense met verskillende belange en benaderings tevrede stel en moet uiters versigtig wees dat hy nie die slagoffer van dubbelpratery word deur botsende antwoorde of inligting aan verskillende persone te verstrek nie.

Derdens verkeer hy in 'n bufferposisie tussen die bedryfsleiding bokant hom en die werknemers onderkant hom. Dit is hy wat moet probeer om die oënskynlike botsende belange, behoeftes en verwagtinge van die bestuur en die werknemers met mekaar te probeer versoen en albei kante tevrede moet stel. Die bedryfsleiding bokant hom verwag dat hy die werk in sy afdeling noukeurig sal beplan en beheer; dat hy sy ondergeskiktes sal dissiplineer en vermorsing sal voorkom; dat goeie prestasies deur die werkers gelewer sal word, ensomeer. Daarteenoor verwag die werknemers onderkant hom dat hy sal toesien dat hulle nie ooreis word nie; dat hulle goeie lone en byvoordele sal ontvang; dat hul werkure nie te lank en hul rusperiodes nie te kort sal wees nie; en dat hulle werkgeluk en -tevredenheid sal ontvang. As skakel tussen die twee groepe moet hy soms minder aangename inligting oordra soos eise van die bestuur dat 'n groot hoeveelheid werk binne 'n kort tydperk voltooi moet word of versoeke van die werknemers om hoër lone en aangenamer werktoestande. As buffer tussen die twee moet die toesighouer die boodskap so oordra dat die 'skok' en ontevredenheid soveel moontlik verminder word. $\mathrm{Hy}$ is beslis 'the man in the middle'.

Vierdens is hy 'n sleutelpersoon in die uitvoering van die daaglikse aktiwiteite van die onderneming en staan hy in die voorste linie van die onderneming se bedrywighede. In sy afdeling word al die voorafgaande beplanning en besluitneming omgesit in die vervaardiging van goedere of die lewering van dienste aan ander afdelings en/of aan die klante van die onderneming. Dit is hier waar goedere en/of dienste vervaardig en/of verkoop moet word, waar instandhoudingswerk gedoen moet word, waar versendings en aflewerings moet plaasvind en waar verskillende soorte administratiewe take uitgevoer moet word - almal aangeleenthede wat vir die voortbestaan van die onderneming van kardinale belang is. Doelmatige taakverrigting is hier besonder belangrik en noodsaaklik en hang in 'n groot mate af van die bekwaamheid van hierdie 'front-line supervisors'.

Vyfdens ontvang hy selde die erkenning, aanvaarding en dank wat hom toekom. Alhoewel hy deel van die bedryfsleiding is, naamlik op die heel laagste vlak daarvan, word hy selde as sulks deur die bedryfsleiding op hoër vlak erken en aanvaar. Hy ontvang selde deelname aan bestuursbesluite en word meestal daarvan in kennis gestel nadat die besluite reeds geneem is en uitgevoer moet word. Hy word meestal slegs beskou as die persoon wat besluite moet oordra en toesien dat hulle uitgevoer word. Hy moet dus die planne, reëls en regulasies, metodes en prosesse wat gewoonlik deur andere opgestel is ten uitvoer bring sonder dat hy sy eie diskresie kan gebruik. As daar dan probleme ontstaan, blameer die bestuur vir hom.

Aan die ander kant ontvang hy ook weinig dank en waardering van sy ondergeskiktes. Hy word as deel van die bestuur beskou en is dus onwelkom in die geledere van die werkers. Hulle hou hom verantwoordelik vir bestuursbesluite, -opdragte, -eise ensomeer en blameer hom vir onbevredigende diensvoorwaardes en werktoestande. Hy is dus die 'sondebok' wat van albei kante beskuldig word.

Sesdens moet hy oor buitengewone en uiteenlopende kennis en vaardighede beskik om sy moeilike taak suksesvol uit te voer. Aan die een kant moet hy oor die nodige tegniese kennis en vaardighede beskik, dit wil sê kennis omtrent al die toerusting, metodes, tegnieke, prosesse, materiale en ander hulpmiddele wat vir die uitvoering van die aktiwiteite gebruik word. Alhoewel hy nie self aan die werklike uitvoering deelneem nie, moet hy nogtans die basiese beginsels goed ken ten einde aan sy ondergeskiktes leiding, voorligting en advies te kan gee. Daarby moet hy oor 'n redelike kennis van die aktiwiteite van ander afdelings beskik; van die onderneming se beleid en prosedures; van die taak van 'n bestuurder; en van metodes en hulpmiddels wat elders gebruik word, soos begrotings, boekhouding, kosteberekening en andere. Aan die ander kant moet hy oor kennis en vaardighede ten opsigte van die bestuur van mense beskik. Hy moet sorg vir gesonde personeelbetrekkinge, vir motivering, goeie kommunikasie, opleiding en dissiplinering op die regte manier. Hy moet te alle tye 'n gesonde balans tussen die tegniese vereistes van sy taak aan die een kant en die menslike element aan die ander kant probeer handhaaf.

In die sewende plek is dit ongelukkig so dat toesighouers nie altyd die opleiding ontvang om hulle vir hulle veeleisende taak te bekwaam nie. In baie gevalle word 'n goeie werker (soos 'n masjienoperateur, die een of ander vakman, 'n goeie verkoopsman, 'n goeie boekhouklerk of die tikster wat die vinnigste kan tik) sonder meer as toesighouer aangestel sonder dat daar seker gemaak word dat hy/sy ook oor bestuurshoedanighede beskik of dat die persoon die nodige praktiese en teoretiese opleiding vir sy/haar nuwe taak as 'n toesighouer ont vang. Hedendaags word persone wat aan die een of ander inrigting (soos 'n universiteit, kollege of instituut) studeer het en die een of ander kwalifikasie verwerf het, soms as toesighouers aangestel sonder dat hulle die nodige praktiese ondervinding opdoen of verdere opleiding binne die onderneming ontvang. Die bedryfsleiding op hoër vlak is dikwels geneig om te veel staat te maak op die gesag wat die toesighouer ontvang en wat hom die reg gee om sekere prestasies van sy ondergeskiktes te verwag sonder dat vasgestel word of die persoon ook oor die vermoë beskik om goeie prestasies moontlik te maak.

In die agtste plek verkeer die toesighouer in sommige op- 
sigte in ' $n$ unieke posisie in vergelyking met ander bedryfsleiers in die onderneming. Hy hou toesig oor lae-vlak niebestuurspersoneel, terwyl bedryfsleiers op die hoër vlakke dikwels slegs oor ander bedryfsleiers direk bevel voer, byvoorbeeld die hoofbestuurder oor die funksionele hoofde en die funksionele hoofde oor afdelingshoofde. Die geaardheid en werkomstandighede van die toesighouer se ondergeskiktes is dus heel anders as dié van die meeste ander bedryfsleiers.

Die toesighouer het ook meestal 'n groter aantal ondergeskiktes as die meeste ander bedryfsleiers. Normaalweg neem die aantal ondergeskiktes per bedryfsteier redelik sterk toe vanaf die top- na die tussen- en daarvandaan na die onderleiding. Hoe groter die aantal ondergeskiktes hoe groter die verskeidenheid geaardhede en hoe moeiliker die bevordering van gesonde betrekkinge en die toepassing van aansporingmetodes.

Die toesighouer se kanse op bevordering is meestal die kleinste van alle bedryfsleiers en die moontlikheid van degradering (as gevolg van onbekwaamheid of 'n afname in aktiwiteite) die grootste, veral as hy/sy uit die geledere van die werkers kom en nie oor besondere kwalifikasies beskik nie.

Die toesighouer se werkplek en kleredrag steek moontlik sleg af by dié van ander bedryfsleiers. Hy dra dikwels 'n oorpak en tel onder die geledere van die blouboordjiewerkers, terwyl die ander bedryfsleiers almal witboordjiewerkers is. In teenstelling met ander bedryfsleiers beskik die toesighouer nie altyd oor 'n aparte kantoor met mooi meubels en allerlei geriewe nie. Dit is so omdat hy so na as moontlik aan sy ondergeskiktes moet wees en/of omdat sy werkplek nie in die kantoorblok geleë is nie, maar in die fabriek, die werkplaas, die magasyn, die winkel of die banklokaal.

In die negende plek het die taak van die toesighouer gedurende die afgelope paar dekades heelwat verander en moeiliker geword. Die veranderinge kan in drie groepe verdeel word, naamlik veranderinge ten opsigte van die taak self, veranderinge ten opsigte van die werkerskorps en veranderinge in die gemeenskap.

Die taak van die toesighouer het aansienlik verander en verander steeds as gevolg van die snelle en volgehoue ontwikkelings op die tegnologiese, elektroniese en ander terreine. Die toerusting en tegnieke waarmee die werk uitgevoer word, word nie alleen al hoe ingewikkelder nie, maar word ook voortdurend deur nuwes vervang. As hoof van die afdeling waar nuwe hulpmiddels en metodes gebruik moet word, is dit noodsaaklik dat die toesighouer oor ' $n$ deeglike kennis daarvan sal beskik sodat hy die leiding kan neem en voorligting kan verskaf by die gebruik daarvan. Dit kan dus maklik gebeur dat die oorspronklike redes vir die bevordering van 'n toesighouer, soos sy tegniese kennis en vaardigheid, later glad nie meer sal bestaan nie, omdat die toerusting en prosedures wat hy as werker gebruik het, heeltemal verouderd geraak het en deur nuwes vervang is.

Daarbenewens word die druk op die toesighouer om produktiwiteit en dus ook die konkurrensievermoë van sy onderneming in vandag se sterk mededingende mark te verhoog, steeds groter. Hy raak dus so vasgevang in die meganika van sy taak, dit wil sê die bemeestering van nuwe toerusting en tegnieke, die bereiking van produksiedoelwitte, die beperking van uitgawes, die lewering van verslae ensomeer, dat hy dikwels vergeet dat hy ook'n aantal mense doeltreffend moet lei en na hulle belange en behoeftes moet omsien.

Ten opsigte van die werkerskorps is die veranderinge seker nie minder ingrypend nie. Die werker van vandag is heeltemal 'n ander mens as sê vier of meer dekades gelede. Vroeèr was die werknemers van een afdeling in die onderneming in vele opsigte ' $\mathrm{n}$ min of meer homogene groep mense wat weinig toesighoudingsprobleme veroorsaak het. Hulle was meestal almal van dieselfde nasionaliteit, ras, geslag en ouderdom, met dieselfde kultuur, tradisies, gewoontes en ideale, en met dieselfde, meestal beperkte, mate van opleiding. Hul vernaamste behoefte en oogmerk was om voldoende te verdien om in hul basiese behoeftes te voorsien en hulle het feitlik geen seggenskap gehad in die vasstelling van hul diensvoorwaardes en werktoestande nie. Hulle taak was om hul hoof se opdragte stiptelik uit te voer, hulle het alle besluite aan hom oorgelaat en het meestal slegs van werkplek verander wanneer dit absoluut noodsaaklik was.

Vandag werk 'n toesighouer met 'n baie meer heterogene groep ondergeskiktes. Daar is dikwels persone van verskillende nasionaliteite, rasse, geslag en ouderdom in sy groep. Daar word byvoorbeeld baie meer van immigrante gebruik gemaak, die aantal vroulike werkers is relatief baie groter, persone van verskillende ras en kleur doen dieselfde werk en mense van verskillende ouderdomsgroepe werk dikwels saam. Die opvoedingspeil van veral die jonger werkers is vandag oor die algemeen baie hoër omdat opleidingsfasiliteite sterk toegeneem het en 'n veel groter persentasie van die bevolking sekondêre en tersiêre opleiding ontvang. Arbeidswisseling kom op redelike groot skaal voor. Omdat werkgeleenthede meestal volop is en werkers voortdurend probeer om hul inkomste te verhoog en beter byvoordele te ontvang, verander hulle maklik van werkplek. Ook hulle geaardhede, hulle behoeftes en doelwitte, inderdaad hulle hele benadering tot hul dagtaak en wat hulle van hulle werk, werkgewer en onmiddellike hoof verwag, het verander. Hulle is minder bereid om onder streng toesig te werk, verlang groter persoonlike vryheid, wil deelneem aan besluitneming en verlang seggenskap in die bepaling van hul diensvoorwaardes en werktoestande.

Vir die toesighouer is dit dus uiters moeilik om sy ondergeskiktes persoonlik te leer ken, hulle behoeftes en doelwitte te peil en te probeer om daarin te voorsien, om te weet hoe om teenoor elkeen op te tree en hoe om spanwerk te bevorder.

Intussen het ook die gemeenskap waarbinne die onderneming funksioneer, van wie hy sy arbeidskragte verkry en van wie hy vir sy voortbestaan afhanklik is, aansienlik verander. Alhoewel dit die toesighouer nie altyd so sterk en direk raak soos die veranderinge ten opsigte van sy taak en die werkerskorps nie, kan hy hom nie daarvan afsonder nie.

Daar bestaan vandag ' $n$ veel groter belangstelling as vroeër by die publiek in die doen en late van sakeondernemings en in hul verantwoordelikhede teenoor die gemeenskap. Daar word noukeurig gelet op die manier waarop ondernemings hul personeellede en hul klante behandel, op die wyse waarop hulle die gemeenskap finansieël en andersins ondersteun en op handelinge wat die gemeenskap se belange ignoreer of benadeel. Daarbenewens word die vryheid en seggenskap van die individu en sy aanspraak op die verwydering van alle struikelblokke in die weg van sy persoonlike ontwikkeling en vooruitgang, vandag hoog aangeslaan. Daar word ook nie geskroom om van allerlei metodes en middele gebruik te maak om hulle wense en 
ideale verwesenlik te sien nie, byvoorbeeld demonstrasies, betogings, petisies, konfrontasies, wegbly van die werk, en selfs werkvertragings, -stopsettings en stakings. Mense se kennis van en benadering tot die lewe word nie alleen deur die hoër opvoedingspeil verander nie, maar dit word ook sterk beinvioed deur die ontwikkeling van kommunikasiemedia soos die pers, radio, televisie en andere. Onder andere maak die minder gegoedes kennis met die welvaart en hoë lewenstandaard van die welvarendes en stel hulle dikwels ongeregverdigde eise of gebruik ontoelaatbare metodes om hul eie posisie te probeer verbeter.

Laastens kan gelet word op die invloed van al die bogenoemde faktore en omstandighede op die persoon van die toesighouer. Sy sekuriteitsgevoel kan sterk aangetas word omdat hy onveilig en onseker oor sy posisie en sy toekoms voel. Hy is onseker oor sy vermoë om die veeleisende taak suksesvol uit te voer, byvoorbeeld of hy kan byhou met die tegnologiese en ander ontwikkelings, of hy sy hoof en ander bedryfsleiers tevrede kan stel, en of sy ondergeskiktes tevrede is met sy optrede. Hy voel ontuis tussen die bedryfsleiers sowel as tussen die werkers omdat nie een van die twee hom in hul geledere verwelkom nie. Hy voel gefrustreerd omdat hy slegs besluite moet uitvoer en nie aan die besluitnemingsproses kan deelneem nie. $\mathrm{Hy}$ twyfel of hy op die lang duur daarin sal kan slaag om die oënskynlike botsende belange en behoeftes van die bestuur en die werkers met mekaar te versoen en die lojaliteit en toewyding van sy ondergeskiktes sal kan behou. Hy sou graag opleiding wil ontvang ten einde sy bekwaamheid te verhoog en sy posisie te verbeter. Hy betwyfel sy eie status en belangrikheid in die onderneming en het 'n swak beeld van homself. Omdat hy teenoor soveel verskillende persone verpligtinge het en soveel mense tevrede moet stel, moet hy uiters versigtig optree en sorg dat hy altyd sy eie posisie beveilig deur sover moontlik aan almal se wense te probeer voldoen.

Die toesighouer moet die onderlinge en komplekse verhouding tussen mense, masjiene en materiale deeglik bestudeer en probeer bemeester. Hy moet steeds onthou dat wat hy ookal doen daar altyd mense en dus personeelbetrekkinge by betrokke is en sal wees en dat hierdie betrekkinge 'n uiters belangrike invloed op die aktiwiteite van sy afdeling en op sy sukses as bedryfsleier uitoefen.

\section{Die bevordering van effektiewe bestuur op die onderleidingvlak}

Doelbewuste aandag aan die volgende aangeleenthede kan veel daartoe bydra dat effektiewe bestuur op die onderleidingvlak bevorder kan word.

Eerstens moet die toesighouer self besef dat hy ' $n$ moeilike maar belangrike taak het om te vervul. As hy vroeër ' $n$ gewone werker was, moet hy homself reoriënteer en insien dat hy voortaan ' $n$ leiersrol moet vervul. Daarby moet hy so gou moontlik probeer aanpas en sorg dat hy die kennis en vaardigheid bekom om alle fasette van sy taak doeltreffend te kan hanteer. Daarvoor is selfstudie en die bywoning van opleidingskursusse nodig en hy moet sorg dat die geleenthede daarvoor tot stand gebring en benut word. Eers wanneer sy eie motivering en oriëntering gedoen is, kan hy probeer om sy veelvuldige pligte en verantwoordelikhede teenoor verskillende persone op verskillende vlakke na te kom.

Tweedens moet die toesighouer konsentreer op sy bestuurstake, dit wil sê hy moet toesien dat die werk ge- doen word, maar hy moet dit nie meer self probeer doen nie. Sy taak is om te beplan en te organiseer, bevel te voer en te beheer. Hy moet oponthoude probeer voorkom en uitskakel, sorg dat die uitvoering vlot verloop, waar nodig regstellings en aanpassings maak en sorg dat elke personeellid sy besondere bydrae na die beste van sy vermoë lewer. Deur self in te spring en die werk te doen sal hy heelwaarskynlik sy bestuurstaak verwaarloos en veroorsaak dat een of meer van sy ondergeskiktes nie sy/hul volle bydrae lewer nie.

Derdens moet die toesighouer sorg vir bevredigende fisiese, tegniese en ekonomiese werkomstandighede. Hy moet sorg vir aangename werkomstandighede deur te verseker dat alle toerusting, materiale en ander hulpmiddele beskikbaar en bruikbaar is, dat elke werker oor die kennis en vermoë beskik om sy taak uit te voer, dat die werkplek skoon en higiënies is, en dat sover hy daartoe ' $n$ bydrae kan maak, die diensvoorwaardes tevredenheid verskaf. Hy moet sy ondergeskiktes aanspoor om alle probleme dadelik onder sy aandag te bring en dan moet hy sonder versuim alle hindernisse uit die weg probeer ruim. Hy moet aanbevelings maak en versoeke tot hoèr instansies rig ten opsigte van beter lone, bevorderings, opleidingfasiliteite, verbetering van die werktoestande ensomeer. Sodoende vergemaklik hy die taak van sy ondergeskiktes en bring groter werkgeluk en -tevredenheid mee.

Vierdens moet hy sy ondergeskiktes goed leer ken en besef dat hulle individue is wat van mekaar verskil en wat nie almal op dieselfde manier behandel moet word nie. Hy moet elkeen se doelwitte en behoeftes ken, sover moontlik elkeen se persoonlike omstandighede en probleme, en elkeen se vermoë en bekwaamhede, maar ook elkeen se tekortkominge. Sodoende moet hy probeer om teenoor elkeen korrek op te tree ten einde hom/haar tot goeie prestasies aan te spoor en elkeen se potensiaal ten volle te benut en te ontwikket. Afgesien van die fisiese, tegniese en ekonomiese omstandighede in die werkplek, moet hy dus ook aan die menslike aspekte aandag skenk en sodoende alle faktore wat die prestasie van sy afdeling kan beinvloed in oorweging neem.

$V y f d e n s$ moet hy sorg vir die korrekte atmosfeer binne sy afdeling ten einde die vrywillige en lojale samewerking van al sy ondergeskiktes te verkry. 'n Atmosfeer wat bereidwilligheid om goeie prestasies te lewer, sal aanhelp, word in 'n baie groot mate deur die houding en optrede van die toesighouer teenoor sy ondergeskiktes bepaal. Die volgende kan hier as voorbeelde genoem word: die manier waarop 'n ondergeskikte aangespreek word by die uitreiking van ' $n$ instruksie of die beantwoording van 'n navraag, die bereikbaarheid en toeganklikheid van die toesighouet vir sy ondergeskiktes, die geduld waarmee hy na hulle luister en die entoesiasme waarmee hy hulle probleme probeer oplos, die objektiwiteit en onpanydigheid waarmee hy sake oorweeg en besluite neem, die beoefening van selfbeheersing en die vermyding van argumente met ondergeskiktes, die vermyding van beloftes wat dalk nie nagekom sal kan word nie, lojaliteit teenoor en ondersteuning en beskerming van sy ondergeskiktes, regverdigheid en billikheid in die uitdeling van werk en die beslegting van geskille, en die verlening van deelname in besluitneming wanneer dit moontlik blyk te wees.

In die sesde plek moet 'n toesighouer te alle tye die kommunikasiekanale tussen hom en sy ondergeskiktes oophou en sorg dat hy suksesvol met hulle kommunikeet. Hy moet toesien dat hy alle inligting wat vir die personeellede van 
belang mag wees aan hulle oordra, soos ondersoeke wat aan die gang is, veranderings wat beoog of aangebring moet word, besluite wat geneem is, probleme wat ondervind en doelwitte wat bereik moet word. Hy moenie skroom om volledige verduidelikings te verstrek wanneer hy byvoorbeeld instruksies uitreik of wysigings aankondig en in werking moet stel nie. Daar moet onthou word dat ondergeskiktes inligting wat hulle ontvang interpreteer soos wat hulle meen hulle daardeur geraak sal word. Besluite wat deur die bedryfsleiding as korrek, logies en in belang van die onderneming beskou word, word nie altyd so deur die werkers verstaan en aanvaar nie. By die oordra van enige boodskap moet die toesighouer seker maak dat die kommunikasie suksesvol is, dit wil sê dat die boodskap wat hy probeer oordra korrek ontvang en geinterpreteer word en die gewenste uitwerking het. Opwaartse kommunikasie vanaf die ondergeskiktes na die toesighouer moet gereeld en korrek plaasvind. Sodoende kan gedagtes vryelik gewissel en onduidelikhede en ontevredenheid maklik en gou uit die weg geruim word.

In die sewende plek moet 'n toesighouer besondere aandag skenk aan sy ondergeskiktes se klagtes, griewe, voorstelle en selfs persoonlike probleme. Hy moet aan sy personeellede toon dat dit hulle vrystaan om enige aangeleentheid onder sy aandag te bring en dat hy met 'n simpatieke oor en 'n oop gemoed na hulle sal luister. Hy moet bereid wees om na andere se standpunte en voorstelle te luister en dit deeglik te oorweeg. Indien hy nie daarmee saamstem nie, moet hy sy redes daarvoor verstrek. Ondergeskiktes moet inderdaad aangemoedig word om voorstelle ter verbetering van die uitvoering van die werk aan hom voor te lê en hulle moet erkenning en dank vir goeie voorstelle ontvang. Klagtes, griewe en ander probleme moet so gou moontlik deeglik ondersoek en die uitslag sonder versuim aan die ondergeskiktes meegedeel word. Die feit dat hul hoof bereid is om na hulle klagtes te luister en daadwerklik aandag daaraan te skenk, is dikwels vir die ondergeskiktes van net soveel waarde as die uiteindelike oplossing van die probleem. Daardeur word hulle aangemoedig om alle aangeleenthede met hul hoof te bespreek en te verseker dat betyds daaraan aandag geskenk word. Sonder om sy neus in hul private sake te steek, moet 'n toesighouer altyd belangstel in sy personeellede se doen en late en bereid wees om hul persoonlike probleme te help oplos wanneer hy daarom gevra word.

In die agtste plek moet die toesighouer probeer om so min direkte toesighouding as moontlik te gebruik. 'n Toesighouer wat voortdurend sy ondergeskiktes dophou maak hulle senuweeagtig, ontwrig hul konsentrasie en verminder hul prestasievermoë. Streng toesighouding wek ook 'n gevoel by die ondergeskiktes dat hul toesighouer hul wantrou en dit doen afbreuk aan die atmosfeer binne die afdeling. Bowendien is die werker van vandag baie minder bereid om streng beheer te word en verlang hy groter vryheid van optrede en groter selfstandigheid. Die toesighouer moet dus probeer om sy ondergeskiktes meer te beinvloed en minder te beheer. Sy invloed moet sodanig wees dat hulle verantwoordelikheidsin so ontwikkel sal word dat streng toesighouding verminder kan word.

In die negende plek moet die toesighouer dissipline altyd baie taktvol toepas. Die feit dat 'n toesighouer vriendelik en bedagsaam teenoor sy ondergeskiktes moet optree, beteken geensins dat hy 'n 'laissez-faire'-houding moet inneem en traagheid en versuim ongestraf moet laat nie. So 'n toesighouer sal gou die respek van sy ondergeskiktes verloor en nie daarin slaag om bevredigende taakuitvoering te bewerkstellig nie. Aan die ander kant moet onthou word dat die toepassing van strafmaatreëls heelwat onaangenaamheid en teenkanting kan meebring. Daar moet dus eerder probeer word om by wyse van positiewe dissipline, byvoorbeeld om personeellede reg te help en geleentheid te gee om te herstel en te vergoed, selfbeheer en selfdissipline te bevorder. Wanneer strafmaatreëls wel toegepas moet word - en daar sal altyd sulke gevalle wees - moet die toesighouer dit met die regte gesindheid en op die regte wyse doen sodat enige nadelige gevolge voorkom kan word. ${ }^{3}$

\section{Slot}

Effektiewe bestuur op die onderleidingvlak is noodsaaklik vir produktiwiteitsverhoging en derhalwe behoort SuidAfrikaanse ondernemings heelwat meer aandag te skenk aan die motivering en opleiding van alle toesighouers. Hierdie persone het geen maklike taak nie, maar nogtans kan veel gedoen word om effektiewe bestuur op daardie vlak te bevorder mits die nodige belangstelling en daadwerklike begeerte bestaan om iets aan die saak te doen.

\section{Summary}

The task of lower management is both complex and important and it is essential that more attention be paid to improving management efficiency at this level.

Factors contributing towards the complexity of supervisory management are mainly the following: The large number and the variety of tasks the supervisor has to perform. The number of persons towards whom the supervisor has some kind of reponsibility, which leads to unremitting pressures from a number of sources. The fact that he has to reconcile the demands of his superiors with the often contrasting wishes of his subordinates. He seldom receives recognition as part of management or acknowledgement for performing his task under most trying conditions. Whilst top and middle managers mostly deal with the problems of other managers, the supervisor has to attend to the problems of non-management personnel whose attitudes and expectations are quite different. The background and experience of the supervisor, mostly being a man from the rank and file, are seldom geared towards performing the functions of management. In spite of this supervisors do not receive sufficient training to improve their management skills as has been revealed by a recent survey in South Africa. Finally, the supervisory function has been subject to radical changes during the last few decades which have increased the complexity of his task and the need for thorough training.

The following are some of the more important suggestions made for improving effective management at supervisory level. A clear understanding of his new role on the part of the supervisor. The supervisor must concentrate on management functions and avoid doing routine work. He must always try to improve the working conditions of his subordinates as well as the atmosphere in the work place. He must know and treat his subordinates individually. He must communicate freely with his workers and pay attention to their grievances, suggestions and personal problems. Direct supervision must be limited to the minimum and con- 
fidence and trust in the ability of the workers must be fostered. Discipline must be applied correctly, justness and fairness towards one and all at all times in both important and unimportant matters, and a team spirit created and maintained through sound communication, motivation and participation.

\section{Venwysings}

1. S.A. Industrial Week. Vol. 3: Nr. 58, 6 April 1982, p. 2.

2. Vergelyk Marx, F.W. 'Personnel motivation and training in South Africa.' Pretoria: Universiteit van Pretoria, Junie 1982.

3. Vergelyk Marx, F.W. Bedryfsleiding, Pretoria: HAUM, 1978, pp. $204-206$. 